\title{
Are known biomarkers for asthma present in early infancy?
}

\author{
M Ayanna Boyce ${ }^{1 *}$, Sanja Stanojevic ${ }^{2}$, Krzysztof Kowalik $^{3}$, Susan Balkovec ${ }^{2}$, Felix Ratjen², Malcolm R Sears ${ }^{4}$, \\ Padmaja Subbarao ${ }^{2}$
}

From Canadian Society of Allergy and Clinical Immunology Annual Scientific Meeting 2013

Toronto, Canada. 3-6 October 2013

\section{Background}

Exhaled nitric oxide $\left(\mathrm{FE}_{\mathrm{NO}}\right)$ is a biomarker for eosinophilic airway inflammation [1]. Elevated $\mathrm{FE}_{\mathrm{NO}}$ has been proposed as a marker for diagnosing asthma and predicting asthma exacerbations [2]. We wished to examine the association between known asthma risk factors and $\mathrm{FE}_{\mathrm{NO}}$. A sub cohort of children $(\mathrm{n}=222)$ participating in the Canadian Healthy Infant Longitudinal Development (CHILD) study underwent infant pulmonary function tests (IPFTs) during the first year of life.

\section{Methods}

Risk factors were obtained from a subset of available CHILD questionnaires administered prenatally and 3 times during the first year of life. $\mathrm{FE}_{\mathrm{NO}}$ was collected using a multiple-breath sampling technique during quiet tidal breathing at the 3 month visit, 1 year visit, or both visits. Prenatal smoke exposure was defined as any maternal smoking, including mothers who stopped or cut down on smoking during pregnancy. Postnatal smoke exposure was defined as any exposure in or away from the home up to 1 year of age. Parental asthma was defined as self-reported or doctor diagnosed asthma. Parental atopic status was confirmed by allergy skin tests. T-tests with Bonferroni correction for multiple comparisons were used to compare $\mathrm{FE}_{\mathrm{NO}}$ in the exposed and unexposed groups $(\alpha=0.004)$.

\section{Results}

At the 3 month visit, 134 infants attended the IPFT lab, and 84 of 117 attempted eNO tests were successfully analyzed; mean $\mathrm{FE}_{\mathrm{NO}}$ was $16.8 \pm 8.1 \mathrm{ppb}$. At the 1 year visit, 181 infants attended the IPFT lab and 138 of 158 attempted eNO tests were successfully analyzed; mean $\mathrm{FE}_{\mathrm{NO}}$ was $15.3 \pm 9.7 \mathrm{ppb}$. Prenatal smoking rates were low (3\% and $6 \%)$ and showed no association with $\mathrm{FE}_{\mathrm{NO}}$ (Table 1). Postnatal smoke exposure was also not associated with $\mathrm{FE}_{\mathrm{NO}}$. $\mathrm{FE}_{\mathrm{NO}}$ was not statistically different in infants whose mothers or fathers had a history of asthma or atopic status, compared to those without. Having siblings was not significantly associated with $\mathrm{FE}_{\mathrm{NO}}$ after applying the Bonferroni correction.

\section{Conclusions}

Smoke exposure was not related to $\mathrm{FE}_{\mathrm{NO}}$, however no nicotine biomarker was assessed and smoking rates were low. Maternal and paternal histories were not associated with $\mathrm{FE}_{\mathrm{NO}}$ levels in healthy children up to 1 year of age. None of the risk factors were statistically significantly associated with $\mathrm{FE}_{\mathrm{NO}}$, however infants with siblings were observed to have a lower $\mathrm{FE}_{\mathrm{NO}}$ than infants without siblings at the 1 year visit. A larger sample size is required to increase the power of these tests. Further factors must be studied to explain the variation in $\mathrm{FE}_{\mathrm{NO}}$ measures seen.

\footnotetext{
* Correspondence: maboyce@uwaterloo.ca

'Faculty of Applied Health Sciences, University of Waterloo, Waterloo,

Canada

Full list of author information is available at the end of the article
} 
Table 1

\begin{tabular}{|c|c|c|c|c|c|}
\hline \multirow{2}{*}{$\begin{array}{l}\text { Variable } \\
\text { Prenatal Smoke Exposure }\end{array}$} & \multicolumn{2}{|c|}{ Testing Time Point } & \multirow{2}{*}{$\begin{array}{l}\text { Sample Size } \\
2\end{array}$} & \multirow{2}{*}{$\frac{\text { Mean } \pm \text { SD (ppb) }}{13.12 \pm 0.8}$} & \multirow{2}{*}{$\begin{array}{l}\text { P value } \\
0.072\end{array}$} \\
\hline & 3 months & Yes & & & \\
\hline & & No & 57 & $15.40 \pm 7.7$ & \\
\hline & 1 Year & Yes & 6 & $21.12 \pm 14.6$ & 0.405 \\
\hline & & No & 100 & $15.63 \pm 9.5$ & \\
\hline \multirow[t]{4}{*}{ Postnatal Smoke Exposure } & 3 months & Yes & 14 & $15.13 \pm 7.5$ & 0.471 \\
\hline & & No & 64 & $16.76 \pm 7.6$ & \\
\hline & 1 Year & Yes & 38 & $13.72 \pm 8.2$ & 0.233 \\
\hline & & No & 99 & $15.73 \pm 10.1$ & \\
\hline \multirow[t]{4}{*}{ Maternal Atopic Status } & 3 months & Yes & 47 & $16.72 \pm 7.5$ & 0.458 \\
\hline & & No & 19 & $15.19 \pm 7.5$ & \\
\hline & 1 Year & Yes & 87 & $15.11 \pm 10.0$ & 0.638 \\
\hline & & No & 40 & $15.94 \pm 8.9$ & \\
\hline \multirow[t]{4}{*}{ Maternal Asthma } & 3 months & Yes & 16 & $17.23 \pm 8.2$ & 0.495 \\
\hline & & No & 49 & $15.62 \pm 7.5$ & \\
\hline & 1 Year & Yes & 29 & $14.50 \pm 7.9$ & 0.460 \\
\hline & & No & 88 & $15.86 \pm 10.3$ & \\
\hline \multirow[t]{4}{*}{ Paternal Atopic Status } & 3 months & Yes & 55 & $16.32 \pm 7.4$ & 0.925 \\
\hline & & No & 12 & $16.07 \pm 8.4$ & \\
\hline & 1 Year & Yes & 87 & $15.13 \pm 9.4$ & 0.085 \\
\hline & & No & 21 & $19.24 \pm 9.5$ & \\
\hline \multirow[t]{4}{*}{ Paternal Asthma } & 3 months & Yes & 10 & $15.45 \pm 10.0$ & 0.962 \\
\hline & & No & 48 & $15.28 \pm 7.2$ & \\
\hline & 1 Year & Yes & 20 & $19.42 \pm 10.1$ & 0.081 \\
\hline & & No & 80 & $14.89 \pm 9.5$ & \\
\hline \multirow[t]{4}{*}{ Sibling } & 3 months & Yes & 30 & $13.54 \pm 8.2$ & 0.065 \\
\hline & & No & 29 & $17.17 \pm 6.5$ & \\
\hline & 1 Year & Yes & 46 & $13.27 \pm 10.0$ & 0.015 \\
\hline & & No & 60 & $17.98 \pm 9.4$ & \\
\hline
\end{tabular}

\section{Authors' details}

${ }^{1}$ Faculty of Applied Health Sciences, University of Waterloo, Waterloo,

Canada. ${ }^{2}$ Respiratory Medicine, Hospital for Sick Children, Toronto, Canada.

${ }^{3}$ Department of Physiology, McGill University, Montreal, Canada.

${ }^{4}$ Department of Medicine, McMaster University, Hamilton, Canada.

\section{Published: 3 March 2014}

\section{References}

1. Gabriele C, Jaddoe WW, van Mastrigt E, Arends LR, Hofman A, Moll HA, de Jongste JC: Exhaled nitric oxide and the risk of wheezing in infancy: the Generation R Study. Eur Respir J 2012, 39:567-572.

2. American Thoracic Society: ATS/ERS Recommendations for Standardized Procedures for the Online and Offline Measurement of Exhaled Lower Respiratory Nitric Oxide and Nasal Nitric Oxide, 2005. Am J Respir Crit Care Med 2005, 171:912-930.

doi:10.1186/1710-1492-10-S1-A48

Cite this article as: Boyce et al: Are known biomarkers for asthma present in early infancy? Allergy, Asthma \& Clinical Immunology 2014 10(Suppl 1):A48.

\section{Submit your next manuscript to BioMed Central} and take full advantage of:

- Convenient online submission

- Thorough peer review

- No space constraints or color figure charges

- Immediate publication on acceptance

- Inclusion in PubMed, CAS, Scopus and Google Scholar

- Research which is freely available for redistribution

Submit your manuscript at www.biomedcentral.com/submit 